Original Article

\title{
Stoichioproteomics study of differentially expressed proteins and pathways in head and neck cancer
}

\author{
Estudo estequioproteômico de proteínas e vias expressas diferencialmente no câncer \\ de cabeça e pescoço
}

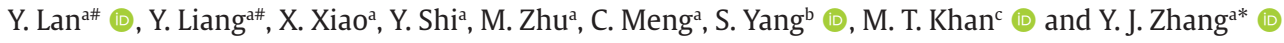 \\ ${ }^{a}$ Chongqing Normal University, College of Life Sciences, Shapingba, Chongqing, P.R. China \\ bNingxia University, School of Life Sciences, Xixia, Yinchuan, Ningxia, P.R. China \\ 'The University of Lahore-Pakistan, Institute of Molecular Biology and Biotechnology, Lahore, Pakistan
}

\begin{abstract}
Hypoxia is a prominent feature of head and neck cancer. However, the oxygen element characteristics of proteins and how they adapt to hypoxia microenvironments of head and neck cancer are still unknown. Human genome sequences and proteins expressed data of head and neck cancer were retrieved from pathology atlas of Human Protein Atlas project. Then compared the oxygen and carbon element contents between proteomes of head and neck cancer and normal oral mucosa-squamous epithelial cells, genome locations, pathways, and functional dissection associated with head and neck cancer were also studied. A total of 902 differentially expressed proteins were observed where the average oxygen content is higher than that of the lowly expressed proteins in head and neck cancer proteins. Further, the average oxygen content of the up regulated proteins was $2.54 \%$ higher than other. None of their coding genes were distributed on the $Y$ chromosome. The up regulated proteins were enriched in endocytosis, apoptosis and regulation of actin cytoskeleton. The increased oxygen contents of the highly expressed and the up regulated proteins might be caused by frequent activity of cytoskeleton and adapted to the rapid growth and fast division of the head and neck cancer cells. The oxygen usage bias and key proteins may help us to understand the mechanisms behind head and neck cancer in targeted therapy, which lays a foundation for the application of stoichioproteomics in targeted therapy and provides promise for potential treatments for head and neck cancer.
\end{abstract}

Keywords: head and neck cancer, hypoxia, oxygen, element usage biases, stoichiogenomics.

\begin{abstract}
Resumo
A hipóxia é uma característica proeminente do câncer de cabeça e pescoço. No entanto, as características do elemento oxigênio das proteínas e como elas se adaptam aos microambientes de hipóxia do câncer de cabeça e pescoço ainda são desconhecidas. Sequências do genoma humano e dados expressos de proteínas de câncer de cabeça e pescoço foram recuperados do atlas de patologia do projeto Human Protein Atlas. Em seguida, comparou o conteúdo do elemento de oxigênio e carbono entre proteomas de câncer de cabeça e pescoço, e células epiteliais escamosas da mucosa oral normal, localizações do genoma, vias e dissecção funcional associada ao câncer de cabeça e pescoço também foram estudadas. Um total de 902 proteínas expressas diferencialmente foi observado onde o conteúdo médio de oxigênio é maior do que as proteínas expressas de forma humilde em proteínas de câncer de cabeça e pescoço. Além disso, o conteúdo médio de oxigênio das proteínas reguladas positivamente foi $2,54 \%$ maior do que das outras. Nenhum de seus genes codificadores foi distribuído no cromossomo Y. As proteínas reguladas positivamente foram enriquecidas em endocitose, apoptose e regulação do citoesqueleto de actina. 0 conteúdo aumentado de oxigênio das proteínas altamente expressas e reguladas pode ser causado pela atividade frequente do citoesqueleto e adaptado ao rápido crescimento e divisão das células cancerosas de cabeça e pescoço. $\mathrm{O}$ viés do uso de oxigênio e as proteínas-chave podem nos ajudar a entender os mecanismos por trás do câncer de cabeça e pescoço na terapia direcionada, o que estabelece uma base para a aplicação da estequioproteômica na terapia direcionada e oferece uma promessa para potenciais tratamentos para o câncer de cabeça e pescoço.
\end{abstract}

Palavras-chave: câncer de cabeça e pescoço, hipóxia, oxigênio, vieses de uso do elemento, estoiciogenômica.

*e-mail: zhangyj@cqnu.edu.cn

\#Equally contributed

Received: March 4, 2021 - Accepted: May 20, 2021

This is an Open Access article distributed under the terms of the Creative Commons Attribution License, which permits unrestricted use, distribution, and reproduction in any medium, provided the original work is properly cited. 


\section{Background}

Head and neck cancer are a collective term which involves the oral cavity, pharynx, and larynx malignant tumors, with prominent characteristics of high incidence and high mortality rates. In 2018, the number of new cases reached 830,000 , and annual mortality rate was about $50 \%$ for head and neck cancer worldwide (Bray et al., 2018). As for China, there are approximately 68000 new cases in 2018 and about 35000 patients die from this disease (Ferlay et al., 2020). It is generally believed that the most illustrative risk factors are tobacco and alcohol, as well as poor oral hygiene, chronic mechanical irritation (Farsi et al., 2017) and HPV infection (Rodríguez Zorrilla et al., 2019). At present, the therapies of head and neck cancer involve surgery, radiotherapy (Karam and Raben, 2019), chemotherapy (Crooker et al., 2018), photodynamic therapy (Cho et al., 2018), and targeted therapy (Nisa et al., 2014). Despite these various therapies, patients always experience posttreatment side effects. For example, they may face speech or swallowing problems which influence their quality of life (Lubek, 2018). It's still far from complete healing for the head and neck cancer.

Hypoxia, a condition of insufficient oxygen supply to tissues, is the prominent feature of human solid cancers (Huang et al., 2014). Hypoxic environment activates a signaling cascade that induces or represses genes transcription, contributing to the plasticity and heterogeneity of tumors and promoting a more aggressive and metastatic phenotype (Jing et al., 2019). In addition, hypoxia is known to be associated with poor clinical outcome, which is particularly true for patients with head and neck cancer (Halmos et al., 2014). The rapid proliferation and growth of head and neck cancer is closely associated with hypoxia (Zhou et al., 2015).

In the era of precision medicine, nucleic acid and protein quantitative technology were used to facilitate the discovery of biomarkers and novel drug targets for molecular therapeutics of head and neck cancer (Babu et al., 2018). Dozens of differentially expressed RNAs and proteins were identified from head and neck squamous cell carcinoma. Among them, three ceRNAs (HCG22, LINC00460 and STC2) LINC00460, HCG22 and STC2 exhibited aberrant levels of expression and significantly correlated with survival (Zhao et al., 2018). However, because of the high costs, only sporadic key proteins were identified by immunohistochemical technologies (Kao and Ulbright, 2020; Yu et al., 2020). Nevertheless, immunohistochemical method is the most accurate proteomics technology, and systematic studies of head and neck cancer based on immunohistochemical data are inadequate. Nowadays, large immunohistochemical data are available from Human Protein Atlas project (HPA) (Uhlen et al., 2015), which provides us with an opportunity to screen proteins associated with head and neck cancer from a systematic proteome perspective. Further research of these proteins is essential to decipher the molecular mechanism underlying head and neck cancer development and progression.

Stoichiogenomics offers a new way to interpret increased genomic, transcriptomic, proteomic and metabonomic data (Jun-Ping et al., 2009; Zhang et al., 2018). Stoichioproteomics holds promises to reveal patterns of differential usages of key elements [e.g. nitrogen $(\mathrm{N})$ ] in proteomes (Zuo et al., 2019; Yin et al., 2019). According to the theory of nutrition limitation (Elser et al., 2011), natural selection biases to the usage of the monomers (amino acid or nucleotide) to reduce constrained element costs in the synthesis of biological macromolecules, when supplies of some elements are constrained in the environment (JunPing et al., 2009). For different biological macromolecules, each of them has different element compositions and contents. Previous study of 9 plant genomes in a proteomescale investigation showed that protein $\mathrm{N}$ content declines with the intensity of gene expression for plants, suggesting plants responded to natural selection caused by nitrogen deficiency via decreased use of $\mathrm{N}$-rich amino acids (Elser et al., 2011). In microbes, like Saccharomyces cerevisiae and Escherichia coli, enzymes involving in the process of certain chemical elements (such as sulphur) have higher content of corresponding elements (BaudouinCornu et al., 2001). So far, it is still unknown whether hypoxic microenvironment of head and neck cancer lessens the oxygen contents of expressed proteins, as expected by nutrition limitation theory.

This study plans to identify key proteins, their genome locations and KEGG enrichment closely related to head and neck cancer based on immunohistochemical data. Further, we hope to analyse the oxygen contents of proteins expressed in head and neck cancer and oral mucosa-squamous epithelial cells, exploring whether an association exists between protein's oxygen contents and their expression levels, and whether hypoxic microenvironment saves oxygen usage as expected by nutrition limitation theory in plant and microbes. This study holds the potential to lay a foundation for the continuing studies and precision treatments of head and neck cancer.

\section{Materials and Methods}

\subsection{Data resource}

Human genome sequences and annotation (version GRCh38.p7) were downloaded from NCBI (ftp://ftp.ncbi.nih.gov/genomes/H_sapiens/). All available immunohistochemical technology-based proteins expressed data of head and neck cancer (with 12,928 proteins expressed) from patients and oral mucosa-squamous epithelial cells (with 11,225 proteins expressed) from normal people were retrieved from pathology atlas of HPA (Human Protein Atlas project, http://www.proteinatlas. org/). Protein expression evaluation included the assessment of staining intensity (negative, weak, medium or strong) and staining cells ( $<25 \%, 25-75 \%$ or $>75 \%$ ) of immunohistochemical images. According to HPA, the degree of a protein's expression is categorized into 4 levels: not detected, low, medium and high, which were further converted to score: $0,3,6$ and 12 . Meanwhile, the expression value of 0 were replaced by 0.1 in differentially expressed proteins identification to make use of experimental data as much as possible. The expression scores (Table S1) of different proteins in different samples were calculated 
using a Perl script we developed. An overview of the technical route was shown (Figure 1).

\subsection{Stoichioproteomics calculations}

The content of an element in multiple sequences was the average value of the element content on the amino acid side chain of all sequences. Element contents in proteins were calculated using algorithms published in the literature (Jun-Ping et al., 2009; Zhang et al., 2014, 2018). The elements in a protein were calculated by using the formula: [ ${ }^{*}$ frequency] $=\sum w i{ }^{*}$ pi $/ L$, where "wi" is the number of * elements in the amino acid side chain (between 0 and 10), pi is the number of $\mathrm{i}$ (an amino acid) in a protein sequence, and $\mathrm{L}$ is the sequence length. The content of an element in multiple sequences is the average value of the element content on the side chain of amino acids in all sequences. In this paper we only considered oxygen and carbon elements. The carbon: oxygen ratio ( $\mathrm{C}: \mathrm{O})$ was calculated as the ratio of carbon atoms to oxygen atoms for the side chain of each protein. All calculations were proceeded using Perl scripts developed our lab.

\subsection{Identification of highly expressed and lowly expressed proteins}

In proteomes of head and neck cancer and oral mucosasquamous epithelial cells, we used three criteria to select highly and the lowly expressed proteins and three groups of data as duplicates. At first, top 3\% proteins with high expression scores were chose as the highly expressed proteins, and the bottom $3 \%$ proteins with low expression scores were the lowly expressed proteins. Secondly, the top $5 \%$ proteins with high expression scores were chose as the highly expressed proteins, and the bottom $5 \%$ proteins with low expression scores were the lowly expressed proteins. Thirdly, threshold (with maximum expression score >=12) proteins were selected as highly expressed proteins, and threshold (with expression score $<=0.1$ ) proteins were selected as lowly expressed proteins.

\subsection{Identification of differential expression proteins (DEPs)}

The expression data were analyzed by "edgeR" (Galperin and Fernández-Suárez, 2012) and "limma" (Ritchie et al., 2015) in statistical software R (2012) (version 3.4.1) to screen differentially expressed proteins. Proteins with $\log 2$ ratio equal or greater than 1 were regarded as the up regulated proteins, and equal or less than - 1 were the down regulated proteins. A $p$ value less than 0.05 was considered statistically significant and FDR level (q-value<0.01) was used to reject false positives (Equation 1).

$\log 2$ ratio $=\log 2\left(\frac{\text { the expression score of proteins in head and neck cancer }}{\text { the expression score of proteins in oral mucosa }- \text { squamous epithelial cell }}\right)(1)$

\subsection{Statistics and visualizations}

$\mathrm{R}$ (version 3.4.1) language was used for statistical analysis. Packages “ggplot2” (Ito and Murphy, 2013), "ggrepel” (Wickham, 2016), and "grid”(Avery, 2002) were used for visualization. Package "circlize" was used to locate genes on genome and "clusterprofiler" (Yu et al., 2012) was used to plot functional enrichment results.

\subsection{Functional enrichment}

KEGG (Kyoto Encyclopedia of Genes and Genomes) database was widely used to elucidate the gene's pathways. KEGG annotations and enrichment were extracted from Gene Set Enrichment Analysis (Ren et al., 2020) (GSEA) (http://software.broadinstitute.org/gsea/index.jsp), which could evaluate whether a priori defined set of interested genes or proteins shows statistically significant differences between two biological states. We selected
Data Acquisition

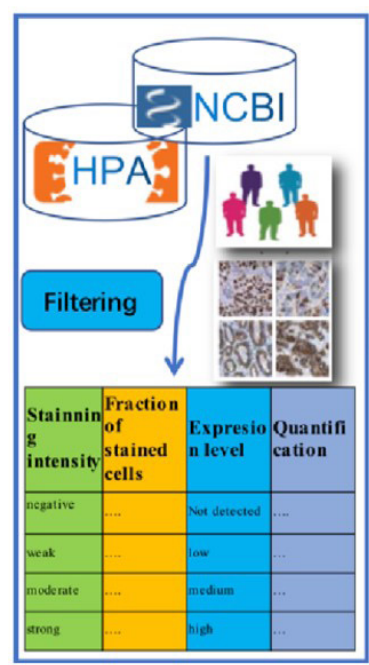

Calculation

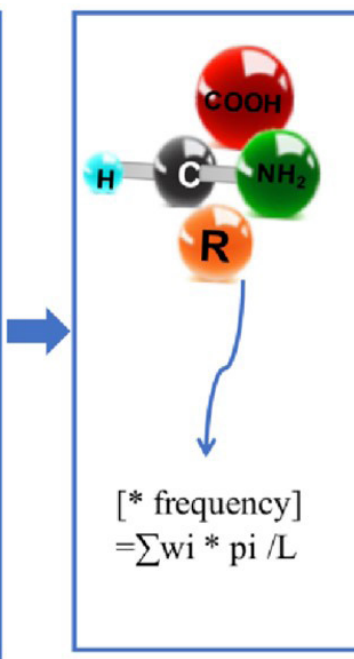

Protein classification

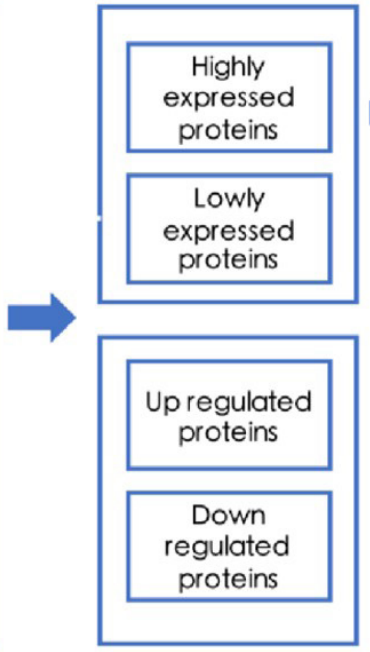

Comparation of Element content

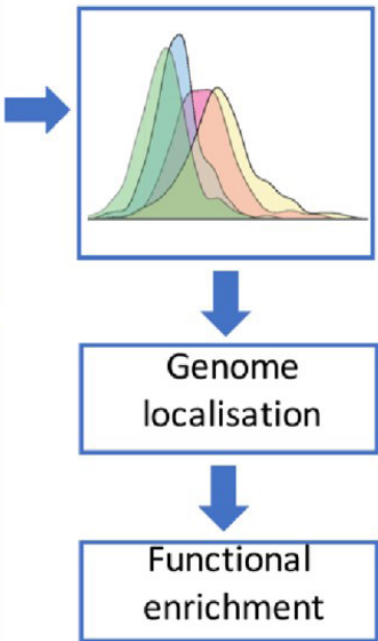

Figure 1. An overview of the technical route of this study. 
top 20 enrichment results with P-value $<0.05$ and FDR value $<0.01$ as the thresholds.

\section{Results}

\subsection{Oxygen and carbon contents of all proteins expressed}

We calculated and compared the oxygen contents of all proteins expressed in head and neck cancer and normal oral mucosas-quamous epithelial cells. The average oxygen content of all expressed proteins was 0.480 in head and neck cancer, and 0.483 in normal oral mucosas-quamous epithelial cell (Table S2). There was no significant difference in proteins' oxygen contents between the two samples $(P=2.41 \mathrm{E}-02$, KS test, Figure 2A, Table S2). Similarly, no significant differences in proteins' carbon contents were detected ( $P=0.1959$, KS test, Figure 2B, Table S2). Although no difference in oxygen contents was detected in this step, we only analysed oxygen contents in all proteins. We did not associate it with protein's expression level.

\subsection{Relationship between proteins' oxygen contents and their expression levels}

To explore the relationship between proteins' oxygen contents and their expression levels, we further calculated and compared the oxygen contents in the highly and the lowly expressed proteins in head and neck cancer and normal oral mucosas-quamous epithelial cells. In order to ensure the reliability of the results, the highly and the lowly expressed proteins were screened out based on the top/bottom 3\%, top/bottom 5\% expressed proteins and proteins with expression score of ${ }^{3} 12 / £ 0.1$. Meanwhile the ratio of carbon to oxygen $(\mathrm{C}: \mathrm{O})$ in each protein was calculated and used as a control for oxygen content. As carbon-to-nitrogen ratios were used as an indicator for nitrogen (Elser et al., 2006), which could reduce the deviation caused by side chain lengthening.

We found that the oxygen content of highly expressed proteins and the lowly expressed proteins were significantly different, and the average oxygen content of the highly expressed proteins was higher than that of the lowly expressed proteins in head and neck cancer (12.44\% for the top/bottom $3 \%, 10.64 \%$ for the top/bottom $5 \%$, and $8.84 \%$ for the threshold proteins) (Figure 3A-C, Table S3). Meanwhile, in normal oral mucosas-quamous epithelial cells, the average oxygen contents of the highly expressed proteins were also higher than that of the lowly expressed proteins (Figure 3D-F, Table S3). But the differences were less pronounced in oral mucosas-quamous epithelial cells than that of the head and neck cancer (Figure 3, Table S3). Furthermore, our results showed that C:O of the highly expressed proteins and the lowly expressed proteins were significantly different in head and neck cancer from the normal oral mucosas-quamous epithelial cells (Figure 3, Table S3), which suggested that a significant difference of oxygen content still existed after elimination of carbon effects.

Results were agreed for proteins expressed at the top/ bottom $3 \%$ or $5 \%$, or proteins with a preset threshold score (Figure 3). All together, these results suggested that there was an association between proteins' oxygen contents and their expression levels in head and neck cancer and normal oral mucosas-quamous epithelial cells, and this association was more pronounced in head and neck cancer cells.

\subsection{Identification of differentially expressed proteins (DEPS) and their genome localization}

All available immunohistochemical data of head and neck cancer from patients and oral mucosa-squamous epithelial cells from normal people were downloaded from HPA and used to identified differentially expressed proteins in head and neck cancer. A total of 902 differentially expressed proteins were screened out, among which 544 were up regulated proteins and 358 were down regulated proteins (Table S5). Then we clarified the genome location of genes encoding the up and down regulated proteins. (Figure 4 ). The genes encoded the up regulated proteins were distributed on 23 chromosomes. Their
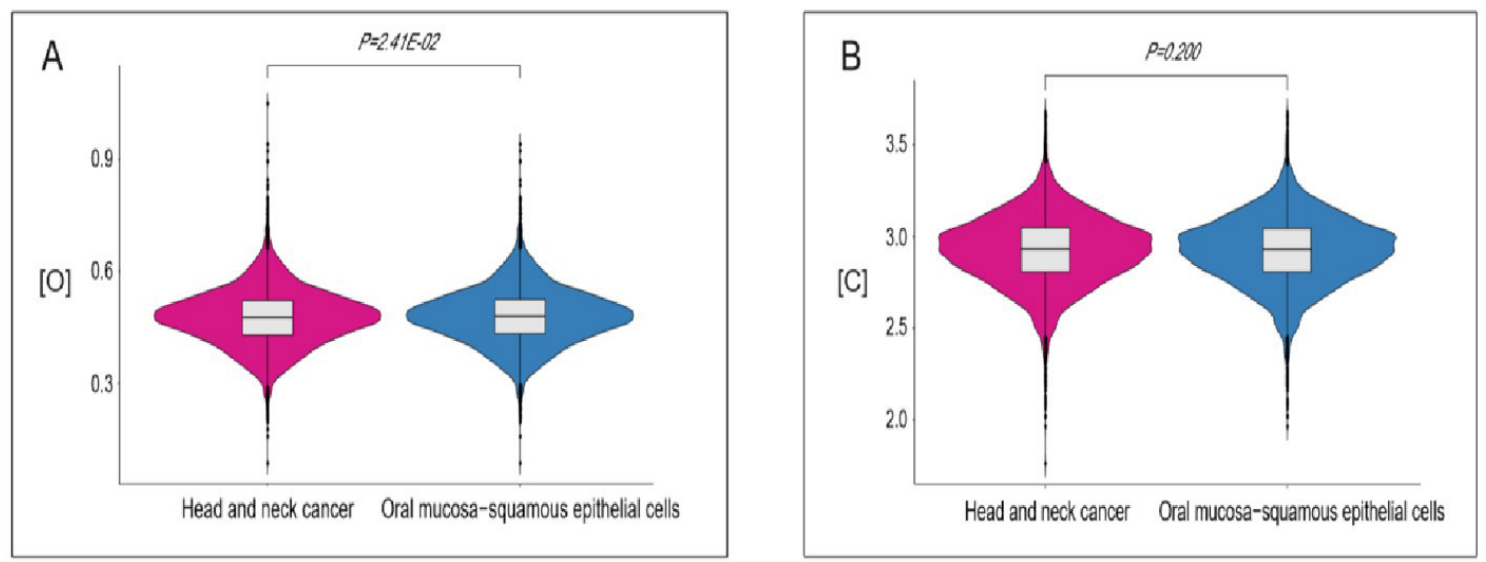

Figure 2. Distribution of oxygen and carbon contents of all expressed proteins in head and neck cancer and normal oral mucosasquamous epithelial cells. (A) Oxygen contents of all expressed proteins; (B) Carbon content of all expressed proteins. Statistic results of KolmogorovSmirnov test were shown. 
[O] of highly expressed proteins

[O] of lowly expressed proteins
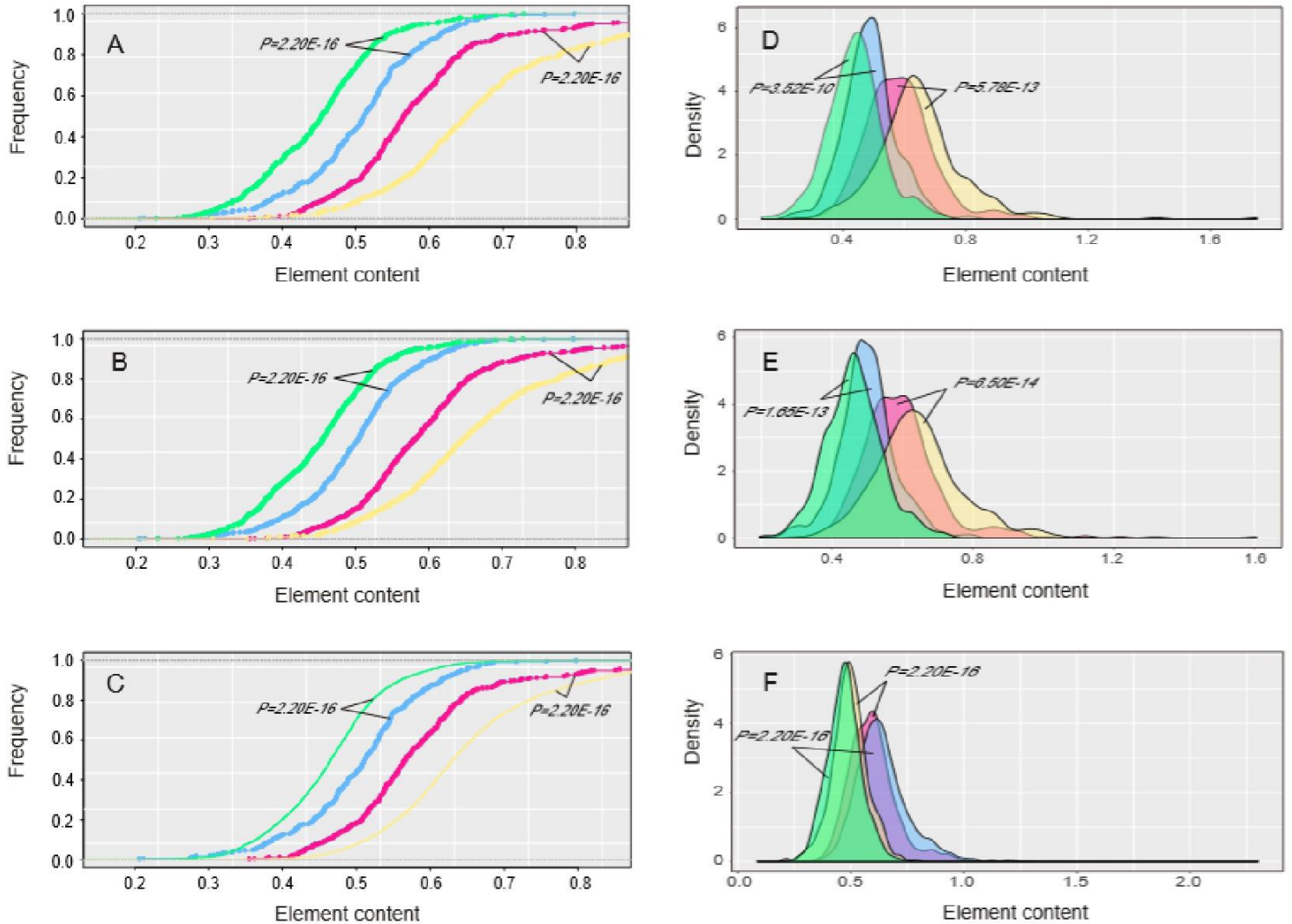

Figure 3. Distribution of oxygen content and C:O ratio of highly and lowly expressed proteins in head and neck cancer and normal oral mucosa-squamous epithelial cells. (A) Comparison of top 3\% highly and lowly expressed proteins in head and neck cancer; (B) Comparison of top 5\% highly and lowly expressed proteins in head and neck cancer; (C) Comparison of threshold highly and lowly expressed proteins in head and neck cancer; (D) Comparison of top 3\% highly and lowly expressed proteins in oral mucosa-squamous epithelial cells; (E) Comparison of top 5\% highly and lowly expressed proteins in oral mucosa-squamous epithelial cells; (F) Comparison of threshold highly and lowly expressed proteins in oral mucosa squamous epithelial cells.

distribution on chromosome 1 was the most with 49 genes, and their distribution on chromosome 13 was the least with only 6 genes. In addition, for the down regulated genes, 39 genes were distributed on the chromosome 1 and only 2 genes on chromosome 13. It is interesting to note that both the up and the down regulated genes were absent from Y chromosome.

\subsection{Relationship between proteins' oxygen contents and} their regulation ratio of differentially expressed proteins (DEPs)

As the above results shown, the oxygen contents of the highly expressed proteins were significantly higher than that of the lowly expressed proteins. We hope to know whether the oxygen contents differ in the up regulated proteins from that in the down regulated proteins. To answer this question, we calculated the oxygen contents of the up regulated proteins and the down regulated proteins. We found that the average oxygen content of the up regulated proteins was $2.54 \%$ higher than that of the down regulated proteins ( 0.484 vs 0.472$)$, which were supported by statistical tests (Table S4). And the distribution of oxygen content between the up regulated proteins and the down regulated proteins were largely separated (Figure 5).

Carbon is one of the key elements that make up organisms, which suggests that carbon is suitable as a control for element composition analysis. Here proteins' carbon contents were used as control for their oxygen contents. In order to make the data of carbon's oxygen elements better presented in the map, we divided carbon content by 10 . The results showed that the average carbon content of DEPs wasn't significantly.

\subsection{Functional enrichment}

Above results showed that the oxygen content of the up regulated proteins is higher than that of the down regulated proteins, which is of great significance to 

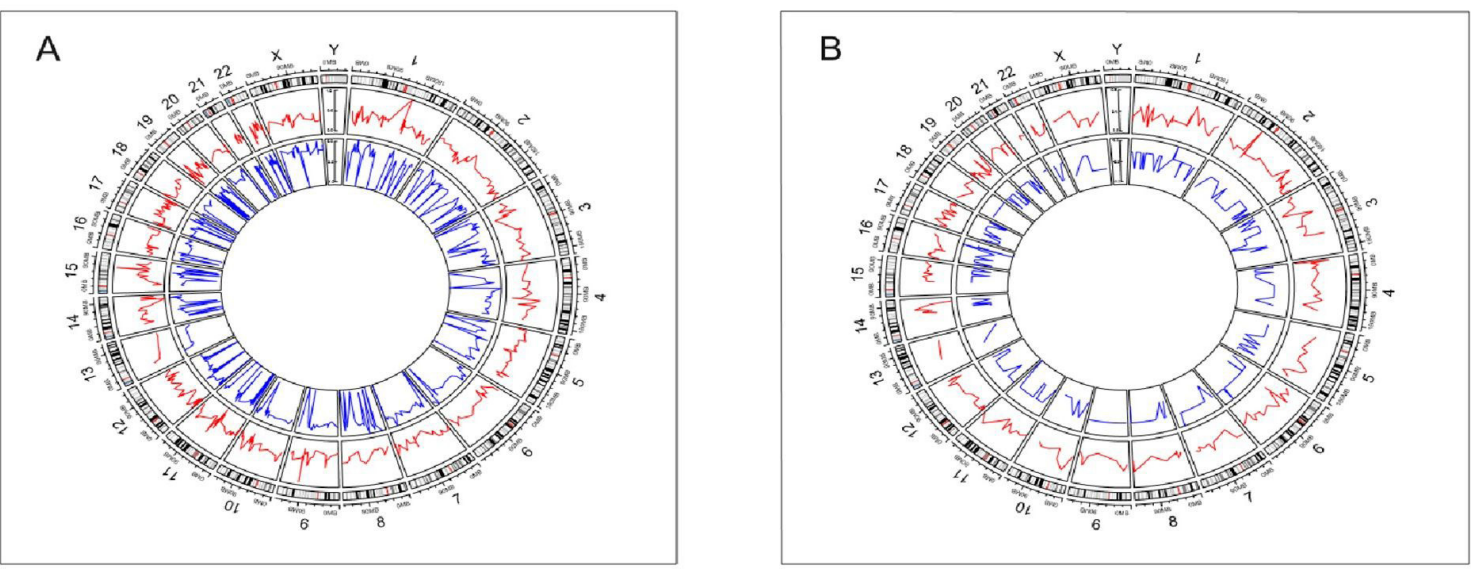

Figure 4. Genome location of genes encoding DEPs, their expression ratio and oxygen content. (A) Genes encoding up regulated proteins; (B) Genes encoding down regulated proteins. The outer circle is the karyogram of human. Red curve reflects the oxygen content of DEPs in the inner circle. Blue curve reflects the expression ratio (log2ratio) of DEPs in middle circle. Different $(P=8.59 \mathrm{E}-01,7.38 \mathrm{E}-01$, KS test, Wilcoxon test, Table S4, Figure 5).

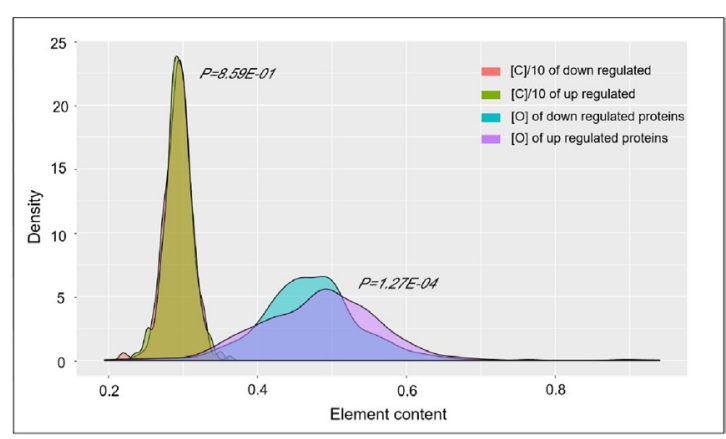

Figure 5. Distribution of up and down regulated proteins' element content in head and neck cancer.

clarify the mechanism of hypoxia driven oxygen element usage bias. Meanwhile, DEPs could help us to reveal the molecular mechanism of head and neck cancer. Therefore, we chose those genes encoding DEPs as key genes and analyze the pathways enriched by them, which could help us to examine large gene lists in a network context efficiently and assemble a summary of the most enriched and pertinent biology.

Functional enrichment analyses were performed respectively for genes encoding the up and the down regulated proteins. Twenty pathways were enriched by the up regulated genes (Figure 6, Table S6), including pathways in cancer (11 genes), cytokine-cytokine receptor interaction(11 genes), endocytosis (10 genes), regulation of actin cytoskeleton (9 genes), ubiquitin mediated proteolysis ( 8 genes), jak-STAT signaling pathway (8 genes), Parkinson's disease ( 7 genes), wnt signaling pathway (7 genes), insulin signaling pathway (7 genes), apoptosis (7 genes), neurotrophin signaling pathway
(6 genes), T cell receptor signaling pathway (6 genes), leukocyte transendothelial migration (6 genes), RIG-Ilike receptor signaling pathway ( 5 genes), small cell lung cancer (5 genes), TGF-beta signaling pathway (5 genes), amino sugar and nucleotide sugar metabolism (4 genes), $\mathrm{N}-$ Glycan biosynthesis (4 genes), Proteasome (4 genes), inositol phosphate metabolism (4 genes). Among them, seven pathways were signaling pathways, which were closely related with the development, proliferation, and migration of the head and neck cancer. In addition, down regulated proteins were only enriched in the pathways of lysosome (6 genes) and peroxisome (5 genes) (Figure 6 , Table S6).

\section{Discussion}

In this study, we screened out 902 differentially expressed proteins including 544 up regulated proteins and 358 down regulated proteins. These proteins provided significance for diagnosis and treatment of head and neck cancer. The genome locations of genes showed their distribution characteristics, and none of these key genes was distributed on the $Y$ chromosome. None of their coding genes were distributed on the $Y$ chromosome, which might affect the incidence rate and mortality of head and neck cancer among men and women. Actually, compared with men, women had an increased relative hazard ratio for death from head and neck cancer (Park et al., 2019). This result lays a foundation for genome study of head and neck cancer. In addition, through KEGG pathway analysis, dozens of pathways were enriched out by the up and the down regulated proteins, which will ultimately help to better understand molecular mechanism of head and neck cancer. 


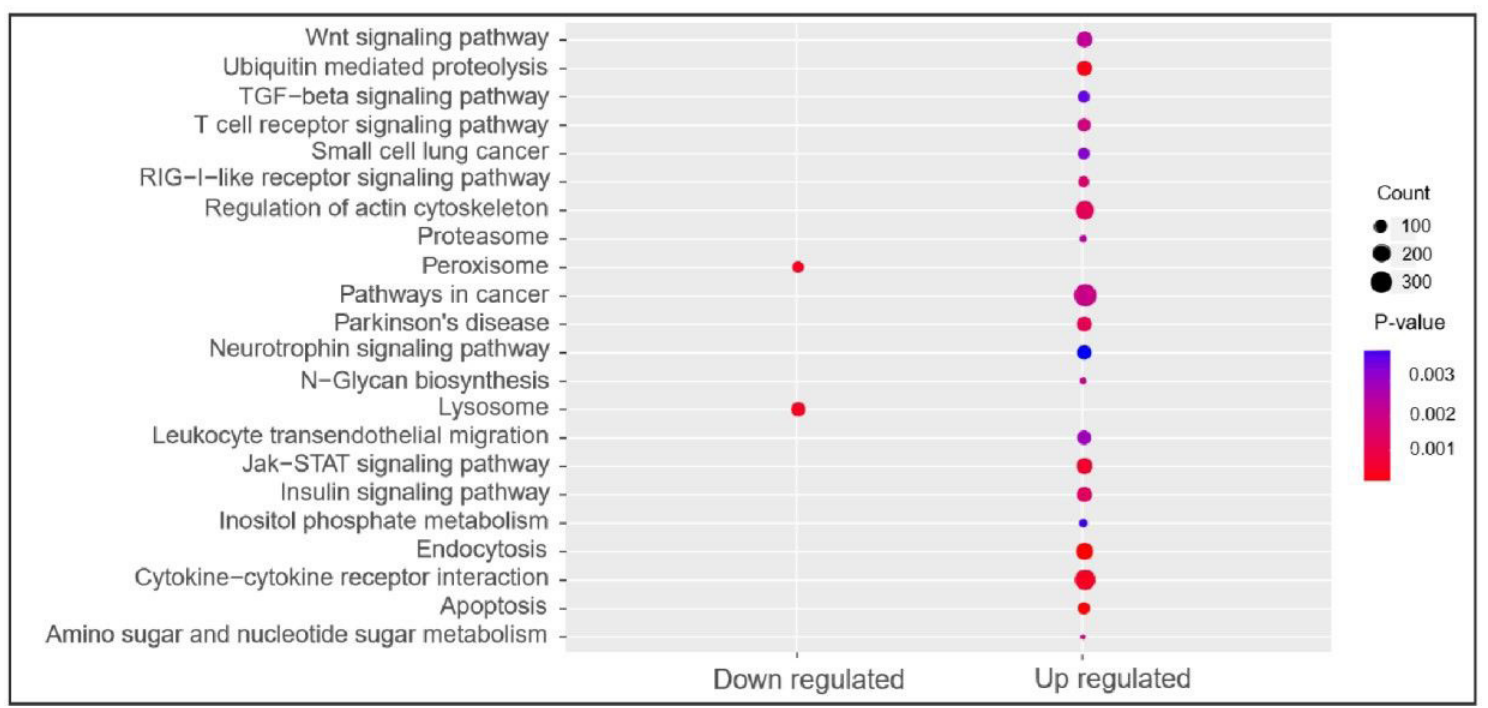

Figure 6. Pathway enrichment of up regulated proteins and down regulated proteins. The size of dots represented number of proteins enriched in each pathway. The color of dot represented P-value.

Seven signaling pathways were enriched out by the up regulated proteins. Among them, wnt signaling pathway is an oncogenic pathway, and its activation maintains the cancer stem cell phenotype and promotes cancer cells' progression (Santarpia et al., 2012). As we all know, Neurotrophin is essential for the growth and survival of neurons. Neurotrophin signaling pathway has connection with a variety of other intracellular signaling pathways. As a report showed, miR-126 down regulated IRS-1 in neurotrophin signaling pathway to enhance the formation of glioma cancer stem cell (Rouigari et al., 2018). However, our study suggested that the up regulation of neurotrophin signaling pathway was associated with the progression of head and neck cancer. The role of neurotrophin signaling pathway needs further experimental verification in the future. In addition, $\mathrm{T}$ cell receptor signaling pathway is bound with the immune response. T cells activated by the external signals will raise their immune functions to promote host defense against cancer (Godfrey et al., 2018). In addition, the up regulated proteins were largely enriched in cell cycle, metastasis (endocytosis and apoptosis, ubiquitin mediated proteolysis) and pathways in cancer. Firstly, the regulation of actin cytoskeleton was enriched out by nine genes. As cell transformation is usually featured by changes in cytoskeletal structure. The regulation of actin cytoskeleton enriched could insure head and neck cancer's migration and proliferation. Secondly, ten genes were enriched in endocytosis and seven genes were enriched in apoptosis. Endocytosis regulates cells' nutrients uptake and it's activity varies during the cell cycle (Jiang and Yan, 2016). Apoptosis is an autonomic ordered programmed cell death aiming to maintain homeostasis (Jiang and Yan, 2016). seven proteins (IL1R1, BCL2L1, PRKAR1B, NFKBIA, CASP10, CHP2, AIFM1) enriched in apoptosis were likely to play a tumor-suppressive role by promoting apoptosis in head and neck cancer. Ubiquitin mediated proteolysis was showed to connected with hypoxia and proteins degradation in cancer cells (Hoppe, 2010). Hypoxia influences ubiquitinmediated proteolysis via IncRNAs (Yang et al., 2014) and a hypoxia-inducible lncRNA NDRG1-OT1_v4 promotes NDRG1 degradation via ubiquitin-mediated proteolysis were evidenced in breast cancer cells (Lin et al., 2017). Thirdly, the up regulated proteins were also enriched in leukocyte trans endothelial migration. Leukocyte migration from the blood into tissues is of crucial for immune surveillance and inflammation (Cook-Mills, 2006).

For the enrichment of the down regulated proteins, pathways of lysosome and peroxisome were enriched out. Lysosome has an important role in sensing and responding to cellular nutrients, growth factors and cellular stress. It shows that lysosome signaling plays an important role in finding new targets for disease-modifying therapies (Lie and Nixon, 2019). In addition, peroxisome dysfunction is related to metabolic disorders in cell (Islinger et al., 2018). The down regulation of peroxisome might lead to the disorder of the body metabolism which accelerated the development of head and neck cancer.

Association of oxygen content and protein expression level in both head and neck cancer and normal oral mucosas-quamous epithelial cells was detected in this study. The average oxygen content of the highly expressed proteins was higher than that of the lowly expressed proteins, which is more significant in head and neck cancer proteomes. For the DEPs, we found that the average oxygen contents of the up regulated proteins were $2.54 \%$ higher than that of the down regulated proteins in head and neck cancer, while no differences of carbon contents were observed. These results showed that the highly expressed and the up regulated proteins consumed more oxygen in head and neck cancer.

Then we did the functional enrichment aiming to explain why the highly expressed and the up regulated proteins consume more oxygen in hypoxia microenvironments of head and neck cancer. Endocytosis, apoptosis and regulation 
of actin cytoskeleton were enriched out by up regulated proteins. Rapid division, proliferation and metastasis of cancer cells require frequent cytoskeleton activity. Previous study had shown that cytoskeleton proteins have higher oxygen elements (Zhang et al., 2018). Therefore, up regulation of these pathways might account for the highly use of oxygen elements by up regulated proteins, which lead to the oxygen usage bias in head and neck cancer.

Our results were not consistent with resource limitation theory (Zuo et al., 2019). According to the theory, natural selection might bias the usage of the monomers (amino acid or nucleotide) to reduce constrained element costs in the synthesis of biological macromolecules (Elser et al., 2011), when the supply of some elements was constrained in environment. High oxygen consumed by the highly expressed and up regulated proteins might be caused by the frequent activities of cytoskeleton occurred in head and neck cancer cells.

\section{Conclusions}

Based on the comprehensive immunohistochemical data, a total of 902 DEPs were detected and their genome locations were illustrated in head and neck cancer. Positive associations between oxygen contents and proteins' expression levels were found in both head and neck cancer and normal oral mucosas-quamous epithelial cells, and this trend is more significant in head and neck cancer cells. Further, we found that the average oxygen content of the up regulated proteins was higher than that of the down regulated proteins. The up regulated proteins were largely enriched in pathways related to cancer, regulation of actin cytoskeleton and endocytosis. We suspected that the highly expressed and up regulated proteins of head and neck cancer consumed more oxygen element were caused by frequent division of the cancer cells. The discovery of oxygen usage bias in head and neck cancer reveals the adaptive mechanisms of proteins. This study screened out key proteins and pathways, which provides useful basis for further research of head and neck and application in precision medicine. Additionally, it helps us to better understand the biological macromolecules associated with head and neck cancer from the stoichioproteomics perspective.

\section{Acknowledgements}

This work was supported by the following, The National Natural Science Foundation of China (31871274, 32060077), and Chongqing Natural Science Foundation and Frontier Research Planning Project (cstc2018jcyjA2487). The funding bodies had no role in the design of the study and collection, analysis and interpretation of data and in writing the manuscript.

\section{Abbreviations}

[C]: Carbon content; [Exp]: Relative expression value; [O]: Oxygen content; DEPs: Differentially expressed proteins;

\section{References}

AVERY, P., 2002. Data Grids: a new computational infrastructure for data-intensive science. Philosophical Transactions. Series A, Mathematical, Physical, and Engineering Sciences, vol. 360, no. 1795, pp. 1191-1209. http://dx.doi.org/10.1098/rsta.2002.0988. PMid:12804274.

BABU, N., MOHAN, S., NANJAPPA, V., CHAVAN, S., ADVANI, J., KHAN, A.A., RENUSE, S., RADHAKRISHNAN, A., PRASAD, T.S.K., KUMAR, R.V., RAY, J.G., BISWAS, M., THIYAGARAJAN, S., CALIFANO, J.A., SIDRANSKY, D., GOWDA, H. and CHATTERJEE, A., 2018. Identification of potential biomarkers of head and neck squamous cell carcinoma using iTRAQ based quantitative proteomic approach. Data in Brief, vol. 19, pp. 1124-1130. http:// dx.doi.org/10.1016/j.dib.2018.05.100. PMid:30225281.

BAUDOUIN-CORNU, P., SURDIN-KERJAN, Y., MARLIÈRE, P. and THOMAS, D., 2001. Molecular evolution of protein atomic composition. Science, vol. 293, no. 5528, pp. 297-300. http:// dx.doi.org/10.1126/science.1061052. PMid:11452124.

BRAY, F., FERLAY, J., SOERJOMATARAM, I., SIEGEL, R.L., TORRE, L.A. and JEMAL, A., 2018. Global cancer statistics 2018: GLOBOCAN estimates of incidence and mortality worldwide for 36 cancers in 185 countries. CA: a Cancer Journal for Clinicians, vol. 68, no. 6, pp. 394-424. http://dx.doi.org/10.3322/caac.21492. PMid:30207593.

CHO, H., ZHENG, H., SUN, Q., SHI, S., HE, Y., AHN, K., KIM, B., KIM, H.E. and KIM, O., 2018. Development of Novel Photosensitizer Using the Buddleja officinalis Extract for Head and Neck Cancer. Evid-Based Complement Altern Med ECAM, vol. 2018, pp.6917590-6917590. http://dx.doi.org/10.1155/2018/6917590. PMid:30026781.

COOK-MILLS, J.M., 2006. Hydrogen peroxide activation of endothelial cell-associated MMPs during VCAM-1-dependent leukocyte migration. Cellular and Molecular Biology, vol. 52, no. 4, pp. 8-16. PMid:17543193.

CROOKER, K., ALIANI, R., ANANTH, M., ARNOLD, L., ANANT, S. and THOMAS, S.M., 2018. A review of promising natural chemopreventive agents for head and neck cancer. Cancer Prevention Research, vol. 11, no. 8, pp. 441-450. http://dx.doi. org/10.1158/1940-6207.CAPR-17-0419. PMid:29602908.

ELSER, J.J., ACQUISTI, C. and KUMAR, S., 2011. Stoichiogenomics: the evolutionary ecology of macromolecular elemental composition. Trends in Ecology E' Evolution, vol. 26, no. 1, pp. 38-44. http:// dx.doi.org/10.1016/j.tree.2010.10.006. PMid:21093095.

ELSER, J.J., FAGAN, W.F., SUBRAMANIAN, S. and KUMAR, S., 2006. Signatures of ecological resource availability in the animal and plant proteomes. Molecular Biology and Evolution, vol. 23, no. 10, pp. 1946-1951. http://dx.doi.org/10.1093/molbev/msl068. PMid:16870683.

FARSI, N.J., ROUSSEAU, M.-C., SCHLECHT, N., CASTONGUAY, G., ALLISON, P., NGUYEN-TAN, P.F., SOULIÉRES, D., COUTLÉE, F., HIER, M., MADATHIL, S., FRANCO, E.L. and NICOLAU, B., 2017. Aetiological heterogeneity of head and neck squamous cell carcinomas: the role of human papillomavirus infections, smoking and alcohol. Carcinogenesis, vol. 38, no. 12, pp. 11881195. http://dx.doi.org/10.1093/carcin/bgx106. PMid:29029021.

FERLAY, J., ERVIK, M., LAM, F., COLOMBET, M., MERY, L., PIÑEROS, M., ZNAOR, A., SOERJOMATARAM, I. and BRAY, F., 2020. [viewed 03 September 2021]. Global Cancer Observatory: Cancer Today. Lyon, France: International Agency for Research on Cancer. [online]. Available from: https://gco.iarc.fr/today.

GALPERIN, M.Y. and FERNÁNDEZ-SUÁREZ, X.M., 2012. The 2012 nucleic acids research database issue and the online molecular biology database collection. Nucleic Acids Research, vol. 40, 
no. Database issue, pp. D1-D8. http://dx.doi.org/10.1093/nar/ gkr1196. PMid:22144685.

GODFREY, D.I., LE NOURS, J., ANDREWS, D.M., ULDRICH, A.P. and ROSSJOHN, J., 2018. Unconventional T cell targets for cancer immunotherapy. Immunity, vol. 48, no. 3, pp. 453-473. http:// dx.doi.org/10.1016/j.immuni.2018.03.009. PMid:29562195.

HALMOS, G.B., BRUINE DE BRUIN, L., LANGENDIJK, J.A., VAN DER LAAN, B.F.A.M., PRUIM, J. and STEENBAKKERS, R.J.H.M., 2014. Head and neck tumor hypoxia imaging by $18 \mathrm{~F}$-Fluoroazomycinarabinoside (18F-FAZA)-PET. Clinical Nuclear Medicine, vol. 39, no. 1, pp. 44-48. http://dx.doi.org/10.1097/RLU.0000000000000286. PMid:24152663.

HOPPE, T., 2010. Life and destruction: ubiquitin-mediated proteolysis in aging and longevity. F1000 Biology Reports, vol. 2, pp. 79-79. http://dx.doi.org/10.3410/B2-79. PMid:21151840.

HUANG, D., LI, C. and ZHANG, H., 2014. Hypoxia and cancer cell metabolism. Acta Biochimica et Biophysica Sinica, vol. 46, no. 3, pp. 214-219. http://dx.doi.org/10.1093/abbs/gmt148. PMid:24389642.

ISLINGER, M., VOELKL, A., FAHIMI, H.D. and SCHRADER, M., 2018. The peroxisome: an update on mysteries 2.0. Histochemistry and Cell Biology, vol. 150, no. 5, pp. 443-471. http://dx.doi. org/10.1007/s00418-018-1722-5. PMid:30219925.

ITO, K. and MURPHY, D., 2013. Application of ggplot2 to pharmacometric graphics. CPT: Pharmacometrics E Systems Pharmacology, vol. 2, no. 10, e79. http://dx.doi.org/10.1038/ psp.2013.56. PMid:24132163.

JIANG, S. and YAN, W., 2016. T-cell immunometabolism against cancer. Cancer Letters, vol. 382, no. 2, pp. 255-258. http://dx.doi. org/10.1016/j.canlet.2016.09.003. PMid:27664755.

JING, X., YANG, F., SHAO, C., WEI, K., XIE, M., SHEN, H. and SHU, Y., 2019. Role of hypoxia in cancer therapy by regulating the tumor microenvironment. Molecular Cancer, vol. 18, no. 1, pp. 157. http://dx.doi.org/10.1186/s12943-019-1089-9. PMid:31711497.

JUN-PING, F., SHAO-YI, B., CHUAN-YI, Y. and LAN-CHUN, Z., 2009. Research on wheelbase preview control for vehicle semi-active suspension based on neural networks. New York: IEEE. http:// dx.doi.org/10.1109/IITA.2009.351.

KAO, C.-S. and ULBRIGHT, T.M., 2020. A morphologic and immunohistochemical comparison of nuclear $\beta$-catenin expressing testicular sertoli cell tumors and pancreatic solid pseudopapillary neoplasms supporting their continued separate classification. The American Journal of Surgical Pathology, vol. 44, no. 8, pp. 1082-1091. http://dx.doi.org/10.1097/ PAS.0000000000001527. PMid:32604170.

KARAM, S.D. and RABEN, D., 2019. Radioimmunotherapy for the treatment of head and neck cancer. The Lancet. Oncology, vol. 20, no. 8, pp. e404-e416. http://dx.doi.org/10.1016/S14702045(19)30306-7. PMid:31364593.

LIE, P.P.Y. and NIXON, R.A., 2019. Lysosome trafficking and signaling in health and neurodegenerative diseases. Neurobiology of Disease, vol. 122, pp. 94-105. http://dx.doi.org/10.1016/j. nbd.2018.05.015. PMid:29859318.

LIN, H.-C., YEH, C.-C., CHAO, L.-Y., TSAI, M.H., CHEN, H.H., CHUANG, E.Y. and LAI, L.C., 2017. The hypoxia-responsive IncRNA NDRGOT1 promotes NDRG1 degradation via ubiquitin-mediated proteolysis in breast cancer cells. Oncotarget, vol. 9, no. 12, pp. 10470-10482. http://dx.doi.org/10.18632/oncotarget.23732. PMid:29535820.

LUBEK, J.E., 2018. Head and neck cancer research and support foundations. Oral and Maxillofacial Surgery Clinics of North America, vol. 30, no. 4, pp. 459-469. http://dx.doi.org/10.1016/j. coms.2018.06.007. PMid:30266190.
NISA, L., AEBERSOLD, D.M., GIGER, R., ZIMMER, Y. and MEDOVÁ, M., 2014. Biological, diagnostic and therapeutic relevance of the MET receptor signaling in head and neck cancer. Pharmacology $\mathcal{E}$ Therapeutics, vol. 143, no. 3, pp. 337-349. http://dx.doi. org/10.1016/j.pharmthera.2014.04.005. PMid:24786972.

PARK, A., ALABASTER, A., SHEN, H., MELL, L.K. and KATZEL, J.A., 2019. Undertreatment of women with locoregionally advanced head and neck cancer. Cancer, vol. 125, no. 17, pp. 3033-3039. http://dx.doi.org/10.1002/cncr.32187. PMid:31090932.

REN, H., LI, H., LI, P., XU, Y., LIU, G. and SUN, L., 2020. Fifteen mRNA-IncRNA expression-based signature predicted the survival of late-staged head and neck squamous cell carcinoma. Bioscience Reports, vol. 40, no. 7, pp. BSR20200442. http://dx.doi. org/10.1042/BSR20200442. PMid:32500914.

RITCHIE, M.E., PHIPSON, B., WU, D., HU, Y., LAW, C.W., SHI, W. and SMYTH, G.K., 2015. limma powers differential expression analyses for RNA-sequencing and microarray studies. Nucleic Acids Research, vol. 43, no. 7, e47. http://dx.doi.org/10.1093/ nar/gkv007. PMid:25605792.

RODRÍGUEZ ZORRILLA, S., GARCÍA GARCÍA, A., BLANCO CARRIÓN, A., GÁNDARA VILA, P., SOMOZA MARTÍN, M., GALLAS TORREIRA, M. and PÉREZ SAYANS, M., 2019. Exosomes in head and neck cancer: updating and revisiting. Journal of Enzyme Inhibition and Medicinal Chemistry, vol. 34, no. 1, pp. 1641-1651. http:// dx.doi.org/10.1080/14756366.2019.1662000. PMid:31496355.

ROUIGARI, M., DEHBASHI, M., GHAEDI, K. and POURHOSSEIN, M., 2018. Targetome analysis revealed involvement of MiR-126 in neurotrophin signaling pathway: a possible role in prevention of glioma development. Cell Journal, vol. 20, no. 2, pp. 150-156. http://dx.doi.org/10.22074/cellj.2018.4901. PMid:29633591.

SANTARPIA, L., LIPPMAN, S.M. and EL-NAGGAR, A.K., 2012. Targeting the MAPK-RAS-RAF signaling pathway in cancer therapy. Expert Opinion on Therapeutic Targets, vol. 16, no. 1, pp. 103-119. http:// dx.doi.org/10.1517/14728222.2011.645805. PMid:22239440.

UHLEN, M., FAGERBERG, L., HALLSTROM, B.M., LINDSKOG, C., OKSVOLD, P., MARDINOGLU, A., SIVERTSSON, Å., KAMPF, C., SJÖSTEDT, E., ASPLUND, A., OLSSON, I., EDLUND, K., LUNDBERG, E., NAVANI, S., SZIGYARTO, C.A., ODEBERG, J., DJUREINOVIC, D., TAKANEN, J.O., HOBER, S., ALM, T., EDQVIST, P.H., BERLING, H., TEGEL, H., MULDER, J., ROCKBERG, J., NILSSON, P., SCHWENK, J.M., HAMSTEN, M., VON FEILITZEN, K., FORSBERG, M., PERSSON, L., JOHANSSON, F., ZWAHLEN, M., VON HEIJNE, G., NIELSEN, J. and PONTÉN, F., 2015. Tissue-based map of the human proteome. Science, vol. 347, no. 6220, pp. 1260419-1260419. http://dx.doi. org/10.1126/science.1260419. PMid:25613900.

WICKHAM, H., 2016. Getting started with ggplot2. Cham: Springer, pp. 11-31. Use R! https://doi.org/10.1007/978-3-319-24277-4_2.

YANG, F., ZHANG, H., MEI, Y. and WU, M., 2014. Reciprocal regulation of HIF- $1 \alpha$ and LincRNA-p21 modulates the warburg effect. Molecular Cell, vol. 53, no. 1, pp. 88-100. http://dx.doi. org/10.1016/j.molcel.2013.11.004. PMid:24316222.

YIN, Y., LI, B., MOU, K., KHAN, M.T., KAUSHIK, A.C., WEI, D. and ZHANG, Y.J., 2019. Stoichioproteomics reveal oxygen usage bias, key proteins and pathways in glioma. BMC Medical Genomics, vol. 12, no. 1, pp. 125. http://dx.doi.org/10.1186/s12920-0190571-y. PMid:31464612.

YU, G., WANG, L.-G., HAN, Y. and HE, Q.-Y., 2012. clusterProfiler: an R package for comparing biological themes among gene clusters. Omics: a Journal of Integrative Biology, vol. 16, no. 5, pp. 284287. http://dx.doi.org/10.1089/omi.2011.0118. PMid:22455463.

YU, X., WU, H., HU, H., DONG, Z., DANG, Y., QI, Q., WANG, Y., DU, S. and LU, Y., 2020. Zein nanoparticles as nontoxic delivery system for maytansine in the treatment of non-small cell lung cancer. 
Drug Delivery, vol. 27, no. 1, pp. 100-109. http://dx.doi.org/10.1 080/10717544.2019.1704942. PMid:31870183.

ZHANG, Y.-J., YANG, C.-L., HAO, Y.-J., LI, Y., CHEN, B. and WEN, J.F., 2014. Macroevolutionary trends of atomic composition and related functional group proportion in eukaryotic and prokaryotic proteins. Gene, vol.534, no. 2, pp. 163-168. http:// dx.doi.org/10.1016/j.gene.2013.10.070. PMid:24262937.

ZHANG, Y.-J., ZHU, C., DING, Y., YAN, Z.W., LI, G.H., LAN, Y., WEN, J.F. and CHEN, B., 2018. Subcellular stoichiogenomics reveal cell evolution and electrostatic interaction mechanisms in cytoskeleton. BMC Genomics, vol. 19, no. 1, pp. 469. http://dx.doi. org/10.1186/s12864-018-4845-0. PMid:29914356.

ZHAO, G., FU, Y., SU, Z. and WU, R., 2018. How long non-coding RNAs and MicroRNAs mediate the endogenous RNA network of head and neck squamous cell carcinoma: a comprehensive analysis. Cellular Physiology and Biochemistry, vol. 50, no. 1, pp. 332-341. http://dx.doi.org/10.1159/000494009. PMid:30282065.

ZHOU, F., ZANGANEH, S., MOHAMMAD, I., DIETZ, C., ABUTEEN, A., SMITH, M.B. and ZHU, Q., 2015. Targeting tumor hypoxia: a third generation 2-nitroimidazole-indocyanine dye-conjugate with improved fluorescent yield. Organic \&'Biomolecular Chemistry, vol. 13 , no. 46, pp. 11220-11227. http://dx.doi.org/10.1039/ C5OB01460C. PMid:26403518.

ZUO, X., LI, B., ZHU, C., YAN, Z.W., LI, M., WANG, X. and ZHANG, Y.J., 2019. Stoichiogenomics reveal oxygen usage bias, key proteins and pathways associated with stomach cancer.Scientific Reports, vol. 9, no. 1, pp. 11344. http://dx.doi.org/10.1038/s41598-01947533-6. PMid:31383879. 


\section{Supplementary material}

Supplementary material accompanies this paper.

Table S1. Evaluation of protein expression scores.

Table S2. Oxygen content and carbon content of all proteins expressed in in head and neck cancer and normal oral mucosa-squamous epithelial cells.

Table S3. Oxygen and carbon content of highly and lowly expressed proteins in in head and neck cancer and normal oral mucosasquamous epithelial cells.

Table S4. Carbon and oxygen content of differentially expressed proteins in head and neck cancer.

Table S5. Differential expressed proteins identified between in head and neck cancer and normal oral mucosa-squamous epithelial cells.

Table S6. Pathways enriched by genes encoding up regulated and down regulated proteins.

This material is available as part of the online article from https://www.scielo.br/j/bjb 